\title{
Isolation, identification and characterization of some bacteria from soil samples of agbaja iron ore mining site of kogi state
}

\begin{abstract}
Hydrometallurgical and other conventional mining technologies on low grade ores require high energy and capital costs. The use of microbes to degrade such type of minerals is gaining acceptance. This study was carried out, therefore to isolate, identify and characterize iron solubilizing bacteria from Iron stones of Agbaja iron ore mining site of Kogi State. Crushed samples in the range of $0.25 \mu \mathrm{m}$ and $0.75 \mu \mathrm{m}$ particle size were used for the isolation. They were cultured in a modified 9k media to facilitate bacterial growth and pure cultures were then isolated and sub-cultured for further identification. Morphological and biochemical analysis suggests that some of the bacteria identified are members of Acidithiobacillus, Pseudomonas, and Leptospirillum species. Also results of growth pattern due to bacteria count obtained after 24 hours, 48hours and 72 hours of incubation ranged between $0.1 \times 103 \mathrm{cfu} / \mathrm{ml}$ and $12.3 \times 103 \mathrm{cfu} / \mathrm{ml}$. The highest count of $12.3 \times 103 \mathrm{cfu} / \mathrm{ml}$ was obtained in Pit 4 at 72 hours. At 24 hours there was no visible count in Pit 5 and 4 , while at 48 hours pit 4 was $1 \times 103$ and pit 5 was $2.6 \times 103$ and finally at 72 hours pit 4 and 5 was $12.3 \times 103$ and $4.3 \times 103$ respectively, incubation time, and temperature, further confirms that these isolated species are mesophilic-acidophiles with good bioleaching properties.
\end{abstract}

Volume 4 Issue 3 - 2017

\section{Ekpa Emmanuel, Adaji Andrew, Odiba C John, lyere, Emmanuel, Ohi Priesley, Dorcas Ufeli, Abubakar Amina}

Department of Biosciences, College of Natural and Applied Sciences, Salem University Lokoja, Nigeria

\author{
Correspondence: Ekpa Emmanuel, Department of \\ Biosciences, College of Natural and Applied Sciences, Salem \\ University Lokoja , Nigeria, Tel +273703613583, \\ Email emmeks@yahoo.co.uk
}

Received: November 03, 2016 | Published: March 16, 2017

Keywords: iron ore, 9k media, bioleaching, bacteria

\section{Introduction}

An ore is a type of rock that contains sufficient minerals with important elements including metals that can be economically extracted from it. ${ }^{1}$ The ores are extracted through mining. The ores are usually rich in iron oxides and vary in colour from dark grey, bright yellow, deep purple, to rusty red. Biomining is a general term used to describe the use of microorganisms to facilitate the extraction of metals from sulfide or iron-containing ores or concentrates. ${ }^{2}$ Bemoaning encompasses two related microbial processes that are useful in extractive metallurgy: bacterial leaching, also known as bioleaching, and bio-oxidation. Sulfides and oxides of metals such as zinc, copper, nickel, and cobalt are almost insoluble in water, but the sulfates of these metals are readily soluble. When the metal sulphide is oxidized to its sulphate, the metal is leached into solution from where it can be extracted.

Bioleaching involves the use of microorganisms to catalyze the oxidation of iron sulfides to create ferric sulphate and sulfuric acid. Ferric sulfate, which is a powerful oxidizing agent, then oxidizes the metal sulfides minerals, which are given above and the metal contained is then leached by the sulfuric acid formed. Current understanding of the mechanism of solubilization is that it is primarily a chemical process, although attachment of microbes to the mineral can enhance dissolution. ${ }^{3}$ This strategy for metal recovery is known as bioleaching because the metal is solubilized in the process. On the other hand, bio-oxidation is an oxidation process caused by the microbes where the valuable metal remains in the solid phase. Likewise, in coal desulfurization, bacteria are used to oxidize the pyrite contaminant in the coal thus making the sulfur soluble as ferric sulfate. ${ }^{4}$ Worldwide reserves of high-grade ores are diminishing at an alarming rate due to the rapid increase in the demand for metals. ${ }^{5}$ World copper production has increased steadily in the period 1984- 2005, from 9 metric ton to 16 metric ton per annum. Likewise, world gold production has risen from 1187 tonne to 2471 tone in the period of $1980-2000 .{ }^{6}$ As higher grade mineral deposits become worked out, there is an increasing need to recover metals from lower-grade mineral deposits.

Bacterial based methods have clear economic advantages in the extraction of metals from many low-grade deposits. Other benefits of the process are its relative simplicity, mild operation conditions, low capital and operating costs, low energy input, and being more environmentally friendly than physical-chemical processes. ${ }^{7}$ Specified another advantage of the process that tailings from bio-mining operations are less chemically active and the biological activity they can support is reduced by the extent to which they have already been bioleached. Mine tailings and wastes produced from physicochemical processes might be biologically leached when exposed to rain and air, producing unwanted acid and metal pollution. The need to mitigate environmental pollution due to discharges from mining activities calls for more studies. The interactions between microorganisms and iron stones needs further investigation, hence the need for this present work. Molecular characterization of the genes responsible for bioleaching capabilities of bacteria begins with isolation and identification of pure cultures. Literature abound with different types of bacteria isolated from various mining sites around the world, there is need therefore to study those from Agbaja. Due to the diversity of micro organisms found within mining sites as reported in different literature, this work was therefore set out; to isolate and identify the various types of bacteria inhabiting such mining sites and to determine the relationship between them and their environment. 


\section{Materials and methods}

\section{Materials}

All reagents and chemicals used in this study were of high analytical grade. Some of the equipment used are include Intelligent Thermostatic Shake Cultivation Cabinet (incubator shaker) made in England, Vertical Heating Pressure Steam Sterilizer (autoclave), Colony Counter, General Laboratory Oven made in and Laboratory Incubator.

\section{Sample collection}

Crushed iron ore samples were collected at different location within Agbaja iron ore mining site from upper layer where most of the microbial activity takes place and thus where most of the bacteria population is concentrated. Iron ore samples were collected using some clean dry and sterile polythene bag along with sterile spatula. $50 \mathrm{~g}$ of the iron ore samples were dissolving in $100 \mathrm{ml}$ of distilled water to make iron ore suspensions and kept on an incubator shaker for 7 days.

\section{Isolation of iron ore bacteria}

$50 \mathrm{~g}$ of each sample of Agbaja iron ore sample was introduced into a conical flask containing $100 \mathrm{ml}$ of distilled water. The $\mathrm{pH}$ was adjusted to between $2.0-5.0$ using $0.1 \mathrm{ml}$ of concentrated sulphuric acid $\left(\mathrm{H}_{2} \mathrm{SO}_{4}\right)$. The conical flasks were plugged with cotton wool. Thereafter the suspension was homogenized and incubated for 7 days in the incubator shaker at $30^{\circ} \mathrm{C}$.

\section{Media preparation}

A $9 \mathrm{~K}$ modified media were used. They contain the following composition; $\mathrm{C}_{6} \mathrm{H}_{12} \mathrm{O}_{6}(25.00 \mathrm{~g}), \mathrm{CO}\left(\mathrm{NH}_{2}\right)_{2}(2.00 \mathrm{~g}), \mathrm{K}_{2} \mathrm{HPO}_{4}(0.25 \mathrm{~g})$, $\mathrm{MgSO}_{4} \cdot 7 \mathrm{H}_{2} \mathrm{O}(0.0625 \mathrm{~g})$. These media were used in order to get colonies of bacteria. The media was autoclaved at a temperature of $121^{\circ} \mathrm{C}$ for 15 minutes. It was allowed to cool, $9 \mathrm{ml}$ of the diluted sample stored previously (in the incubator shaker) was pipette into sterilize petrish dish. The cooled media was also dispensed into Petri dish and allowed to gel, and incubated for 24 hours at $37^{\circ} \mathrm{C}$. They were cultured in a modified $9 \mathrm{~K}$ media to facilitate and maintain bacteria growth.

\section{Sample inoculation}

Portions of the suspension were inoculated on the nutrient agar by streaking and were incubated at $37^{\circ} \mathrm{C}$ for 24 hours. Then the bacteria strains were isolated from iron ore samples.

\section{Examinations of purified bacteria cultures}

In order to identify the purified cultures tentatively on the gram staining and various biochemical tests were performed namely; catalase test, oxidase test, and growth in $\mathrm{NaCl}$ test, etc.

\section{Morphology}

The colony morphology was viewed with the aid of a colony counter. Morphological characteristics such as colony, edges, surface, and elevation were observed.

\section{Gram staining8}

A drop of distilled water was placed on a clean glass slide and a loop of the bacterial isolate was smeared on the water which was then allowed to dry. It was then passed through a flame twice in order to heat fix it. One to two drops of crystal violet was added and left for 60 seconds before washing it with distilled water. Grams iodine was added and washed away with distilled water after 1minute. It was then flooded with alcohol (ethanol) and washed with distilled water after 30seconds and then adding safranin which was also washed with distilled water after 30 seconds. The glass slide was left to dry and examined under the microscope.

\section{Biochemical identification}

\section{Catalase test8}

This is a test to ascertain the ability to produce Catalase that reduces hydrogen peroxide to water and oxygen. On a clean glass slide, a smear of the organisms was made in a drop of normal saline with a flame sterilized wire loop. Thereafter, a drop of hydrogen peroxide was placed on the smeared organism. If effervescence occurs, it is confirmatory positive test for catalase production, but if it does not occur it is negative test for catalase production.

\section{Oxidase test8}

A piece of filter paper was soaked in oxidase reagent and the paper placed in a clean sterilized petri-dish. With an inoculating loop, a smear of the organism was made in a drop of normal saline on the filter paper and left for 30seconds. Purple colour shows a positive test, colorless is negative.

\section{Growth in $\mathrm{NaCl}$}

This is a test to ascertain the ability of the isolate to tolerate high salt concentration. About $(7 \mathrm{~g})$ of $\mathrm{NaCl}$ was dissolved in $100 \mathrm{ml}(7 \%$ solution) of Nutrient agar and was poured into slant bottles. The isolate was inoculated into the medium; incubation was for 24 hours at room temperature.

\section{Results and discussion}

\section{Total bacteria count}

The total bacteria count for the Ore samples are shown in Figures $1 \& 2$. The result obtained after 24hours, 48 hours and 72 hours of incubation ranged between $0 \times 10^{3} \mathrm{cfu} / \mathrm{ml}$ and $12.3 \times 10^{3} \mathrm{cfu} / \mathrm{ml}$. The highest count of $12.3 \times 10^{3} \mathrm{cfu} / \mathrm{ml}$ was obtained in Pit 4 at 72 hours. At 24 hours there was no visible count in Pit 5 and 4 , while at 48 hours pit 4 was $1 \times 10^{3}$ and pit 5 was $2.6 \times 10^{3}$ and finally at 72 hours pit 4 and 5 was $12.3 \times 10^{3}$ and $4.3 \times 10^{3}$ respectively.

\section{Growth rate of bacteria}

The growth rate of bacteria present in iron ore sample are shown in Figures $3 \& 4$, Pit 4 had a peak growth rate of $83 \%$ at 48 hours, and least growth rate of 0 at 24 hours. Pit 5 had a peak growth rate of $100 \%$ at 48 hours and least at 24 hours.

\section{Discussion}

Results of Isolation, Identification and Characterization of bacteria from Agbaja iron ore mining site is shown in Table 1 \& Figures 1-5 respectively. A simple modified enrichment $9 \mathrm{~K}$ media for the growth of iron oxidizing bacteria shows that it possess certain advantages than the conventional nutrient agar. ${ }^{9}$ Some of these advantages include: Easy preparation, Rapid growth of cultured organism and appearance of large visible colonies that are easily identifiable..$^{10}$ Reported that 
normal nutrient agar inhibits the growth of iron oxidizing bacteria. The results of morphological and Biochemical Characterization (Table 1) shows that some of the bacteria belong to the Acidithiobacillus species and a few other Bacillus species that have been well documented in literature. ${ }^{11}$ Also results of growth pattern due to bacterial count, incubation time, and temperature (Figures 1-5) further confirms that these isolated species are mesophilic-acidophiles in agreement with. ${ }^{12}$

Generally, metal mobilization from rocks, mineral soil and other substrates can be achieved by proteolysis, complication by excreted metabolites and iron (iii) binding via methylation. ${ }^{2}$ This result in volatilization. It has been shown that microbes can also mobilize metals and attack mineral surfaces by redox processes. ${ }^{13}$ For example, bacterial iron (iii) reduction results in release of some metals like Fe, Mn, and Co, from goethite ore (like those of Agbaja). Growth pattern observed in this studies shows optimum at 48hours and $37^{\circ} \mathrm{C}$ respectively. This might not be far from the fact that most Acidithiobacillus species of bacteria are mesophilicacidophiles. ${ }^{14}$ One can say that the optimum growth seen at 48hours is an indication of the log phase of the organisms presently availability of nutrients and less competition.

The frequency of the observed species of bacteria within this mining site may be attributed to the presence of Siderophore. ${ }^{15}$ These are the largest class of known compounds that can bind and transport or shuttle iron across microbial cells. They are excreted by a wide variety of bacteria (Bacillus species inclusive). They aid iron assimilating by these organisms. ${ }^{16}$ It has been established that iron is the only known essential element for which these specific organic shuttles operate. Organisms like the ones identified in this work have evolved mechanisms to ensure that iron demand is met through the production of species specific siderophores or by attachment to a solid iron mineral like goethite used for this work. ${ }^{13}$ Some bacteria of Acidithiobacillus species, Leptospirillum species, and Pseudomonas species (all identified in this work) have the ability to oxidize ferrous iron enzymatically with concomitant energy generation as reported by. ${ }^{17}$ This too may have informed the observed growth kinetics of the graphs (Figures 1-5). Iron (iii) may also be locally concentrated by adsorption to microbial surfaces and metal oxides. Microbial (bacterial) formation of hydrous iron oxides in aqueous environments may cause accumulation of other metal ions by co-precipitation or adsorption. Such adsorped metals may be remobilized by the reduction of the iron oxides or acidification. ${ }^{18}$

Microbes (bacteria and fungi) play a key geoactive roles in the biosphere, particularly in the ares of biotransformation, biogeochemical cycling, metal and mineral transformation, bioweathering and soil sediment formation. Microbes have a variety of properties that can effect changes in metal speciation, toxicity, and mobility, as well as mineral formation or dissolution. ${ }^{19-50}$ The ubiquity and importance of microbes in the biosphere make geomicrobiology one of the most important phenomenoum requiring an interdisciplinary approach to define environmental and biotechnology exploitation. From this work and the results observes in the choice of media growth kinetics and identifiable bacteria (Figures 1-5) it can be seen that microbes (bacteria) interacts with metals and minerals in both natural and synthetic environment. These alter both the physical and chemical state of this metals which aid microbial growth, activity, and survival. It can therefore be conducted that many minerals are biogenic origin, and formation of such biominerals of global geological and industrial significance. ${ }^{51-71}$

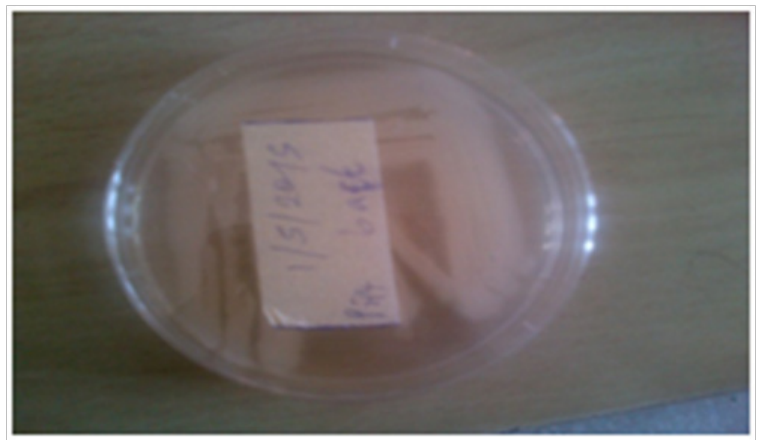

Plate I N=57; Epidemiological distribution of the pathological fractures, traumatic fractures, and nonunion.

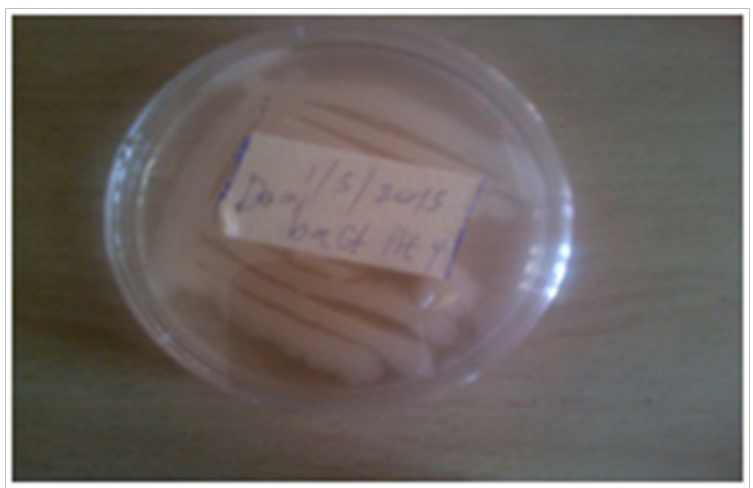

Plate $2 \mathrm{~N}=57$; Epidemiological distribution of the pathological fractures, traumatic fractures, and nonunion. 


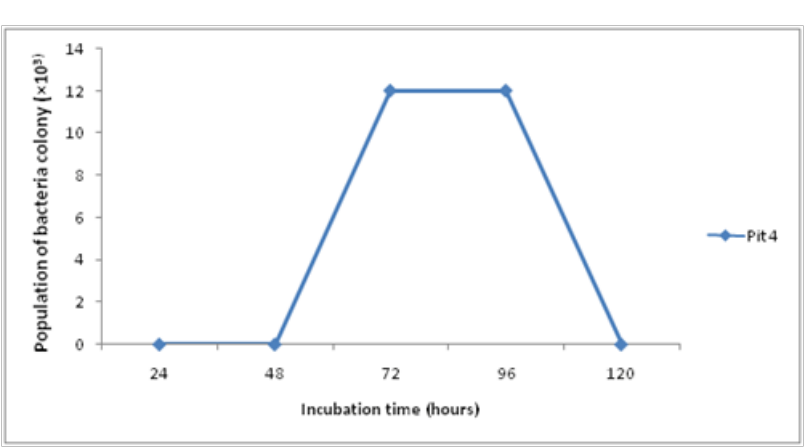

Figure I $\mathrm{N}=57$; Epidemiological distribution of the pathological fractures, traumatic fractures, and nonunion.

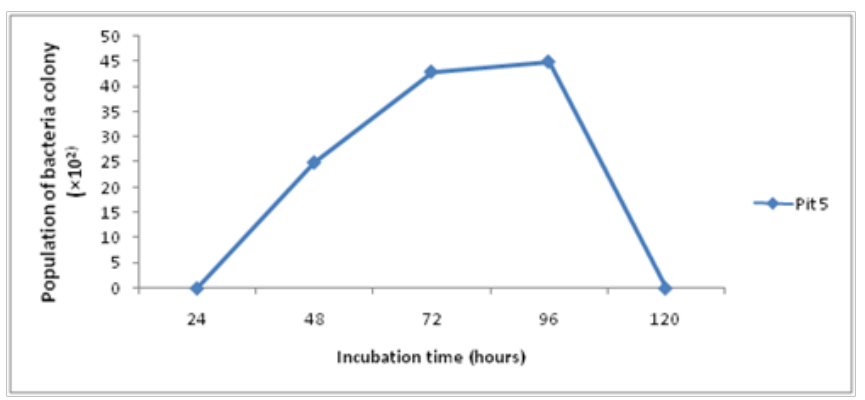

Figure $2 \mathrm{~N}=57$; Epidemiological distribution of the pathological fractures, traumatic fractures, and nonunion.

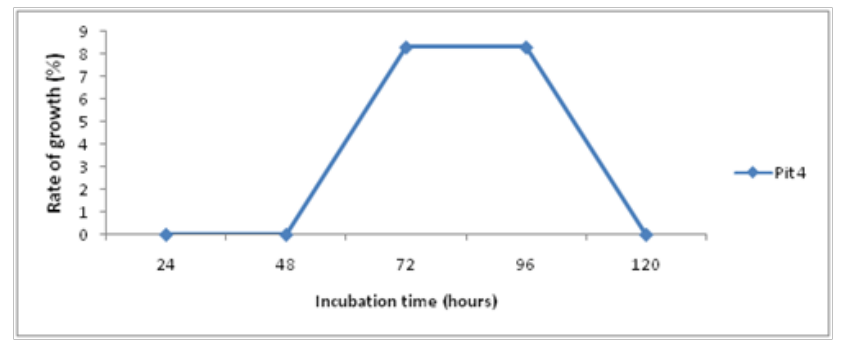

Figure $3 \mathrm{~N}=57$; Epidemiological distribution of the pathological fractures, traumatic fractures, and nonunion.

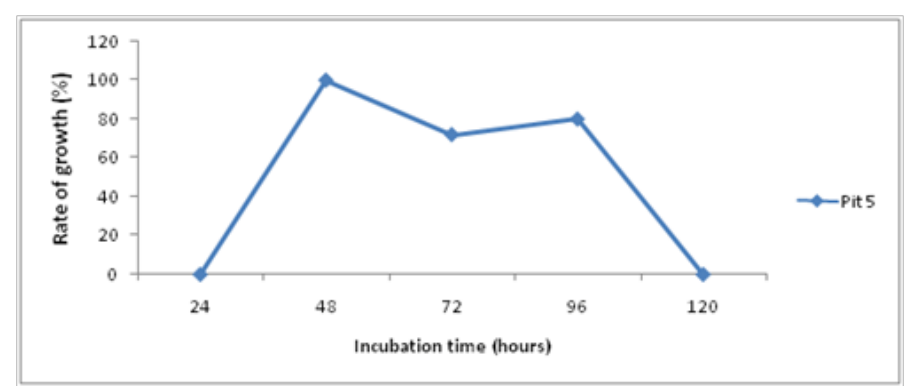

Figure $4 \mathrm{~N}=57$; Epidemiological distribution of the pathological fractures, traumatic fractures, and nonunion.
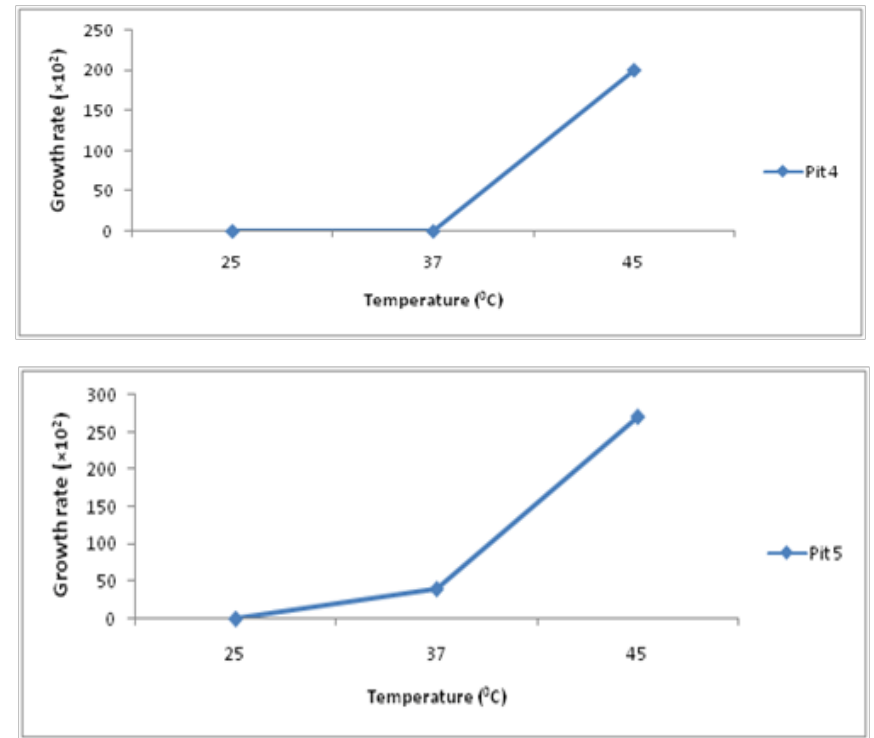

Figure $5 \mathrm{~N}=57$; Epidemiological distribution of the pathological fractures, traumatic fractures, and nonunion.

\section{Table I Identification and characterization of isolates}

\begin{tabular}{|c|c|c|c|c|c|c|c|c|c|c|c|c|c|c|c|c|}
\hline 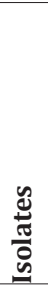 & E્ة & $\frac{\vdots}{0}$ & 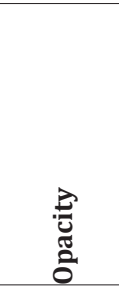 & 总 & $\begin{array}{l}\stackrel{0}{0} \\
\stackrel{0}{0} \\
\stackrel{0}{0}\end{array}$ & 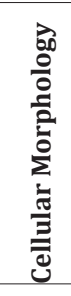 & 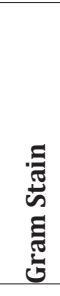 & 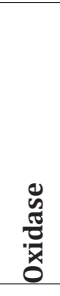 & $\begin{array}{l}\ddot{y} \\
\frac{\tilde{g}}{\pi} \\
\frac{\pi}{\pi} \\
\tilde{J}\end{array}$ & $\begin{array}{l}\bar{\Xi} \\
\tilde{\pi}\end{array}$ & 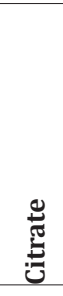 & 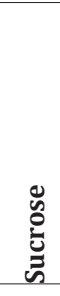 & 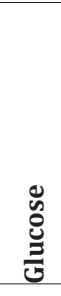 & 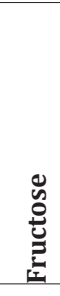 & 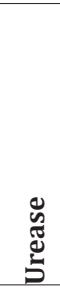 & 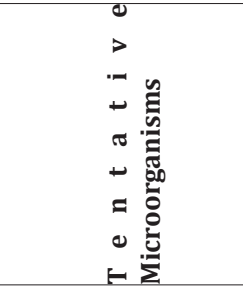 \\
\hline 1 & Circular & White & Opaque & Entire & Flat & Rod & - & - & + & - & + & $\mathrm{A}$ & A & A & + & Acidithiobacillusspp \\
\hline 2 & Circular & Cream & Opaque & Entire & Flat & Rod & - & - & - & - & + & + & + & A & - & Leptospirallumspp \\
\hline 3 & Irregular & White & Opaque & Lobate & Raised & Rod & + & + & + & - & + & + & A & A & + & Pseudomonas spp \\
\hline
\end{tabular}




\section{Acknowledgements}

None.

\section{Conflict of interest}

The author declares no conflict of interest

\section{References}

1. Rawlings DE, DB Johnson. The microbiology of Biomining: Development and optimization of mineral oxidizing microbial consortia. Microbiology. 2007;153(2):315-324.

2. Olson GJ, Brierley JA, Brierley CL. Bioleaching review part B:progress in bioleaching: applications of the microbial processes by the mineral industries. Appl Microbiol Biotechnol. 2003;63(3):249-257.

3. Romano P, Blazquez ML, Alguacil FJ, et al. Comparative study on the selective chalcopyrite bioleaching of a molybdenite concentrate with mesophilic and thermophilic bacteria. FEMS MicrobiolLett. 2001;196(1):71-75.

4. Schippers A, Sand W. Bacteria leaching of metal sulfides proceeds by two indirect mechanisms via thiosulfate or via polysulfide and sulfur. Applied Environmental Microbiology. 2007;65(1):319-321.

5. Rohwerder T, Gehrke T, Kinzler K, et al. Bioleaching review part A:Progress in bioleaching: fundamentals and mechanisms of bacterial metal sulfide oxidation. Appl Microbiol Biotechnology. 2003;63(3):239248

6. Tempel K. Commercial biooxidation challenges at Newmont's Nevada operations. USA: SME Annual Meeting; 2003.

7. Rawlings DE, Dew D, Du, et al. Biomineralization of metal-containing ores and concentrates. Trends Biotechnology. 2003;21(1):38-44.

8. Fawole MO, BA Oso. Laboratory Manuals of Microbiology. Nigeria: Spectrum Books ltd; 2004. 127 p.

9. Petri R, Podgorsek L, Imhoff JF. Phylogeny and distribution of the sox B gene among thiosulfate-oxidizing bacteria. FEM Microbiol Lett. 2001;197(2):171-178.

10. Karkhane M, Mohseni S, Sepehr Sh, et al. Large production of indigenous Acidithiobacillusferrooxidansin modified solid media and investigation its ability in copper bioleaching. J Microbial Biotechnol. 2010;1(3):4349

11. Xia, Jin-lan, Peng, et al. A new strain Acidithiobacillus albertensis BY05 for bioleaching of metal sulphides ores. Transactions of Nonferrous Metals Society of China. 2007;17(1):168-175.

12. DE Rawlings. Heavy metal mining using microbes, Annual Review of designated genera Acidithiobacillusgen., nov., Halothiobacillusgen., nov, and Thermithiobacillus gen. nov. J Syst Envol Microbial. 2002;50:511516

13. Handelsman J. Metagenomics: application of genomics to uncultured microorganisms. Microbiol Mol Biol Rev. 2004;68(4):669-685.

14. Natarajan KA, Deo N. Role of bacterial interaction and bioreagents in iron ore flotation. Int J Miner Process. 2001;62(1-4):143-157.

15. Okibe N, Gericke M, Hallberg KB, et al. Enumeration and Characterization of acidophilic Microoraganisms Isolated from a Pilot Plant Stirred-tank bioleaching Operation. Appl Environ Microbiol. 2003;69(4):1936-1943.

16. Kelly DP, Wood AP. Reclassification of some species of Thiobacillusto the newly designated genera Acidithiobacillusgen nov, Halothiobacillusgen nov and Thermithiobacillus gen. nov. Int J Syst Envol Microbial. 2000;50 Pt 2:511-516.
17. Nengwu Zhu, Yun Xiang, Ting, et al. Bioleaching of Metal Concentrates of Waste Printed Circuit Boards by Mixed Culture of acidophilic bacteria. J Hazard Mater. 2011;192(2):614-619.

18. Pacholewski A, M Pacholewska. Natural ability to the oxidation of iron (11) by iron bacteria from mineral springs Lomniczanka. Current Problems of Hydrogeology X. 2001:389-396.

19. Abdel-Aai EA. Kinetics of Sulphuric Acid Leaching of Low grade Zinc Silicate Ore. Hydrometallurgy. 2000;55(3):247-254.

20. Acharya C, Kar RN, Sukla LB. Bioleaching of Low Grade Manganese Ore with Penicilliumcitrinum. Eur $J$ Miner Process Environ Prot. 2002;2(3):197-204.

21. Akinci G, Guven DE. Bioleaching of heavy metals contaminated sediment by pure and mixed cultures of Acidithiobacillussp. Desalination 2011;268(1-3):221-226.

22. Baskaran V, Nemati M. Anaerobic reduction of sulfate in immobilized cell bioreactors, using a microbial culture originated from an oil reservoir Biochemical Engineering Journal. 2006;31(2):148-159.

23. Brandi H, Bosshard R, Wegmann M. Computer-munching microbes: metal leaching from electronic scrap by bacteria and fungi. Hydrometallurgy. 2000;59(2-3):319-326.

24. Brierley JA, Brierley CL. Present and future commercial applications of biohydrometallurgy. Hydrometallurgy. 2001;59(2-3):233-239.

25. Chen BY, Liu HL, Chen YW, et al. Dose-response assessment of metal toxicity upon indigenous Thiobacillusthiooxidans BC1. Process Biochemistry. 2004;39(6):737- 748.

26. Craven P, Morales P. The Billiton-Codelco strategy for commercializing copper bioleaching. In: Copper hydromet roundtable. Randol Golden Colo. 2000:119-126.

27. Crundwell FK. Modeling, simulation, and optimization of bacterial leaching reactors. Biotechnol Bioeng. 2001;71(4):255-265.

28. Debaraj Mishra, Dong-Jim Kim, DE Ralph, et al. Bioleaching of metals from spent lithium ion secondary batteries using Acidithiobacillusferrooxidans. Waste Management. 2008;28(2):333-338.

29. Gadd GM. Metals, minerals and microbes: geomicrobiology and bioremediation. Microbiol. 2010;156(3):609-643.

30. Galleguillos P, Remonsellez F, Galleguillos F, et al. Identification of differentially expressed genes in an industrial bioleaching heap processing low-grade copper sulphide ore elucidated by RNA arbitrarily primed polymerase chain reaction. Hydrometallurgy. 2008;94(1-4):148-154

31. Liang G, mo Y, Zhou Q. Novel Strategies of Bioleaching Metals from Printed Circuit Boards (PCBs) in Mixed Cultivation of two acidophiles. Enzyme and Microbial Technology. 2010;47(7):322-326.

32. Ehrlich HL. Geomicrobiology. 4th ed. USA: Marcel Dekker; 2002.

33. Handelsman J. Metagenomics: application of genomics to uncultured microorganisms. Microbiol Mol Biol Rev. 2004;68(4):669-685.

34. Huber R, Sacher M, Vollman A, et al. Respiration of arsenate and selenate by hyperthermophilic Archaea. Syst Appl Microbiol. 2000;23(3):305-314.

35. International Journal of Water Resources and Environmental Engineering. 2012.

36. Jin J, Shi S, Liu G, et al. Arsenopyrite bioleaching by Acidithiobacillus ferrooxidansin a rotating-drum reactor. Miner Eng. 2012;39:19-22.

37. Johnson DB. Biodiversity and interactions of acidophiles: Key to understanding and optimizing microbial processing of ores and concentrates. Trans Nonferrous Metals Society China. 2010;18(6):13671373 
38. Anyakwo CN, Obot OW Laboratory Studies on Phosphorus Removal from Nigeria's Agbaja Iron Ore by Bacillus Subtilis. Journal of Minerals \& Materials Characterization \& Engineering. 2011;10(9):817-825.

39. Karkhane M, Mohseni S, Sepehr Sh, et al. Large production of indigenous Acidithiobacillusferrooxidansin modified solid media and investigation its ability in copper bioleaching. J Microbial Biotechnol. 2010;1(3):4349.

40. Mishra D, Kim DJ, Ralph DE, et al. Bioleaching of spent hydroprocessing catalyst using acidophilic bacteria and its Kinetics aspect. Journal of Hazardous Materials. 2008;152(3):1082-1091.

41. Mutch LA, Watling HR, Watkin ELJ. Population Dynamics of a Low-Grade Chalcopyrite Bioleaching Column. Adv Materials Res. 2009;71:71-74.

42. Natarajan KA, Deo N. Role of bacterial interaction and bioreagents in iron ore flotation. Int J Miner Process. 2001;62(1-4):143-157.

43. Nengwu Zhu, Yu Xiang, Ting Zhang, et al. Bioleaching of Meta Concentrates of Waste Printed Circuit Boards by Mixed Culture of acidophilic bacteria. J Hazard Mater. 2011;192(2):614-619.

44. Okibe N, Gericke M, Hallberg KB, et al. Enumeration and Characterization of acidophilic Microoraganisms Isolated from a Pilot Plant Stirred-tank bioleaching Operation. Appl Environ Microbiol. 2003;69(4):1936-1943.

45. Olson GJ, Brierley JA, Brierley CL. Bioleaching review part B: progress in bioleaching: applications of the microbial processes by the mineral industries. Appl Microbiol Biotechnol. 2003;63(3):249-257.

46. Pacholewski A, Pacholewska M. Natural ability to the oxidation of iron (11) by iron bacteria from mineral springs Lomniczanka. Current Problems of Hydrogeology X. 2001:389-396.

47. Panda S, Sanjay K, Sukla LB, et al. Insights into heap bioleaching of lowgrade chalcopyrite ores:A pilot scale study. Hydrometallurgy. 2012;125126:157-165.

48. Pathaka A, MG Dastidar, TR Sreekrishnan. Bioleaching of heavy metals from sewage sludge by indigenous iron-oxidizing microorganisms using ammonium ferrous sulphate and ferrous sulphate as energy sources. A comparative study. J Hazard Mater. 2009;171(1-3):273-278.

49. Petri R, Podgorsek L, Imhoff JF. Phylogeny and distribution of the sox B gene among thiosulfate-oxidizing bacteria. FEMS Microbiol Lett. 2001;197(2):171-178.

50. Power IM, Dipple GM, Southan G. Bioleaching of Ultramafic Tailings by Acidithiobacillus spp. For CO2 Sequestration. Environ Sci and Technol. 2010;44(1):456-462.

51. Pradhan N, Nathsarm KC, Rao KS, et al. Heap bioleaching of chalcopyrite: a review. Miner Eng. 2008;21(5):355-365.

52. Pradhan N, Nayak RR, Mishra DK, et al. Microbial Treatment of Lateritic $\mathrm{Ni}$-ore for Iron Beneficiation and Their Characterization. World Environ. 2012;2(6):110-115

53. Raschman P, Fedorockova A. Study the inhibition Effect of Acid Concentration on the Dissolution Rate of Magnesium Oxide during the Leaching of Dead-burned Magnesite. Hydrometallurgy. 2004;71:403.

54. Rohwerder T, Gehrke T, Kinzler K, et al. Bioleaching review part A: Progress in bioleaching: fundamentals and mechanisms of bacterial metal sulfide oxidation. Appl Microbiol Biotechnol. 2003;63(3):239-248.
55. Romano P, Blazquez ML, Alguacil FJ, et al. Comparative study on the selective chalcopyrite bioleaching of a molybdenite concentrate with mesophilic and thermophilic bacteria. FEMS Microbiol Lett. 2001;196(1):71-75.

56. Santini JM, Sly LI, Schnagl RD, et al. A new chemolithotrophic arsenite-oxidizing bacterium isolated from a gold mine: Phylogenetic, physiological, and preliminary biochemical studies. Appl Environ Microbiol. 2000;66(1):92-97.

57. Scheckel KG, Sparks DL. Dissolution Kinetics of Nickel Surface Precipitates on Clay Mineral and Oxide Surfaces. Soil sci soc Am J. 2001;65:685.

58. Schippers A, Sand W. Bacteria leaching of metal sulfides proceeds by two indirect mechanisms via thiosulfate or via polysulfide and sulfur. Appl Environ Microbiol. 2007;65(1):319-321.

59. Sethurajan M, Aruliah R, Karthikeyan OP, et al. Bioleaching of copper from black shale ore using mesophilic mixed populations in an air uplift bioreactor. Environmental Engineering and Management Journal. 2012;11(3):1839-1848.

60. Simate GS, Ndlovu S, Gericke M. The effect of elemental sulphur and pyrite on the leaching of nickel late rites using chemolithotrophic bacteria. Hydrometallurgy Conference, 2009:155-166.

61. Staden P, van Rhodes M, Martinez T. Piloting and feasibility study of a bioleach process for the treatment of polymetallic base metal concentrate. Abstracts of the Annual Meeting of the Society for Mining, Metallurgy and Exploration. 2003. p. 24-26.

62. Streit WR, Schmitz RA, Metagenomics. The key to the uncultured microbes. Curr Opin Microbiol. 2004;7(5):492-498.

63. Štyriaková I. Factors Affecting Bioleaching in the Processing of NonMetallic's. Nova Biotechnology. 2007;5(1):11-16.

64. Tang JA, Valix M. Leaching of low grade limonite and nontronite ores by fungi metabolic acids. Minerals Engineering. 2006;19(12):1274-1279.

65. Tao Yang, Zheng Xu, Jiankang Wen, et al. Factors influencing Bioleaching Copper from Waste Printed Circuit Boards by Acidithiobacillus ferrooxidans. Hydrometallurgy. 2008;97(1-2):29-32.

66. Valix M, Usai F, Malik R. Fungal bioleaching of low grade lateritic ores. Minerals Engineering. 2001;14(2):197-203.

67. Wakeman K, Auvinen H, Johnson DB. Microbiological and geochemical dynamics in simulated-heap leaching of a polymetallic sulfide ore. Biotechnology Boeings. 2008;101(4):739-750.

68. Wang J, Bai J, Xu J, et al. Bioleaching of Metals from Printed Wire Boards by Acidithiobacillus ferrooxidans and Acidithiobacillus thiooxidans and their mixture. J Hazard Mater. 2009;172(2-3):1100-1105.

69. Watling HR. The bioleaching of sulphide minerals with emphasis on copper sulphides- a review. Hydrometallurgy. 2006;84(1-2):81-108.

70. Williams KP, Kelly DP. Proposal for a new class within the proteobacteria, Acidithiobacillus, with the Acidithiobacillales as the type order. Int $j$ Syst Evol Microbiol. 2013;63(8):2901-2906.

71. Xia, Jin-lan, Peng, et al. A new strain Acidithiobacillusalbertensis BY05 for bioleaching of metal sulphides ores. Transactions of Nonferrous Metals Society of China. 2007;17(1):168-175. 